\title{
The Inner Circle of Power on Twitter? How Politicians and Journalists Form a Virtual Network Elite in Finland
}

\author{
Iiris Ruoho*, Jaana Kuusipalo** \\ * Faculty of Information Technology and Communication, Tampere University, Finland \\ ** Faculty of Social Sciences, Tampere University, Finland
}

Abstract

\begin{abstract}
Top-level politicians and political journalists have been key actors in public discussion necessary for a democratic political system and transparent political decision-making. This article presents an empirical social network analysis showing the connections between Finnish top-level politicians and political journalists on Twitter and the construction of mediated political and media elites in this specific context. The article argues that there is a need to take seriously the Twitter as a medium and the new ways of networking provided by the digital, hybrid media environment in particular. The results of our empirical study suggest that it may even be relevant to talk about mediated elites, which have emerged under the new social condition created by the digitalization of media, culture, and society.
\end{abstract}

Keywords: Political communication; mediated elites; digitalization of media.

Submitted: 4th June 2018

Accepted: 28th November 2018

\section{Introduction}

Twitter, like other microblogging platforms, tends to encourage some forms of political communication while limiting others (van Dijck, 2013), which may spawn new types of elite networks. Politicians use platforms such as Twitter to gain and maintain political support and participate in political debates (e.g. Graham, Jackson, \& Broersma, 2016, pp. 768-769). Thus, politicians' online presence reflects new practices of political representation. For political journalists, the Internet and social media have become essential tools for seeking information and building professional networks. In fact, the use of Twitter and other networked platforms has largely been incorporated into journalists' daily routines (Lasorsa, Lewis, \& Holton, 2012, p. 22) and has provided them with a new way of storytelling (Papacharissi, 2016). ${ }^{1}$

As the most popular social media site among political and media elites in Finland, Twitter seems to be a particularly relevant media platform for the study of elite networks in the Finnish context (Twittercensus, 2013; Vainikka \& Huhtamäki, 2015, p. 180). Top-level politicians and political journalists are key actors in public discussions, which are necessary for a democratic political system and transparent political decisionmaking. In the previous study (Ruoho, Kuusipalo, Vainikka, \& Huhtamäki, $2014^{2}$ and Ruoho \& Kuusipalo, 2018) on the social networks between Finnish politicians and political journalists, we asked how an online public space, such as Twitter, tends to modify political representation, democracy and equality.

The aim of this article is to discuss the main results of the empirical research on the networks within and between Finnish political and journalistic elites in the context of elite research. It argues that there is a need to take seriously Twitter as a medium and the new ways of networking provided by the digital, hybrid media environment in particular. The results of the empirical study suggest that it may even be relevant to talk 
about mediated elites, who have emerged under the new social conditions created by the digitalisation of media, culture and society (e.g. Couldry \& Hepp, 2017; Hepp \& Krotz, 2014; Hepp, Hjarvard, \& Lundby, 2015).

Our original network analysis certainly provides only frozen snapshots of the networks of Finnish elites at a particular moment. However, the results demonstrate that in addition to the traditional elites of formal politics and mainstream media, virtual elites, such as a 'Twitter elite' of politicians and journalists, exist. This suggests that increasing numbers of prominent politicians and political journalists may be moving into a new stage in their relationship to networking through their use of Twitter.

The article starts with a discussion of the myth of mediated power and how this myth works with the key players in politics and journalism. After delving into the mediatisation of politics and journalism, the article covers some theoretical challenges that elite research is facing in the digital environment. These challenges are discussed along with the presentation of the main results of the empirical study on the Twitter networks of Finnish political and journalistic elites. The article ends with some concluding remarks that provide new insights for elite research by suggesting new ways to study elites of the digital age.

\section{Myth of mediated power}

The idea that a society has a 'centre' ('the myth of the centre') represented by the media ('the myth of the mediated centre') has been considered fundamental to the discursive power wielded by the media (Couldry, 2003, p. 45; cf. Jensen, 2015, pp. 189-190). The political elite tries to sway public opinion via the media, whereas political journalists maintain the myth of the mediated centre by reporting on topical political issues, which are assumed to reflect 'what is really going on right now'. Accordingly, one could argue that Twitter is doing its part to maintain the myth of the mediated centre. This is not only because of the type of political communication or content that it encourages but also because, in terms of the personification of politics, it offers an advantage in the game of visibility and popularity, as this article will show.

Today, the contemporary digital media environment is creating new dynamics for social life and producing new social constellations. Micro-blogging services, such as Twitter, are unique in their methods of moulding social relations and networks in a specific context, making it possible to argue that the social is being constructed from, and through, technologically mediated processes and infrastructures of communication that one used to call 'media'. One can even argue that as one of these microblogging services, Twitter builds its own kind of social world (Latour, 2005) with its own logics and ideas about political representation, democracy and equality.

Instead of assuming that media, in one way or another, colonise politics (Meyer \& Hinchman, 2002) or that politics takes control of media, the article argues that in the digital and hybrid media environments, Twitter offers political and journalistic elites a unique platform for both gaining public attention and networking. Thus, the theoretical interest lies in the media-related interaction between and among virtual elites, on one hand, and Twitter as a medium that shapes this communication, on the other hand. At the centre of our debate is the concept of mediatisation, which represents for us a new social condition in which the role and influence of media on culture and society are assumed to change. Yet there are ongoing debates both for and against the strength of media in political communication and the relationship of media (or journalism) 
as an institution to other social institutions and policymakers (e.g. Couldry \& Hepp, 2017; Esser \& Strömbäck, 2014; Hjarvard, 2013; Kammer, 2013; Kunelius \& Reunanen, 2016; Lundby, 2009; Witschge, 2014).

As Andreas Hepp (2013) argues, in communication theory, mediatisation encompasses two disparate traditions - namely, the institutional tradition and the socio-constructivist tradition (p. 616). The former has, until recently, mainly focused on traditional mass media, whose influence is described as 'media logic', whereas the latter is targeted more towards everyday communication practices - especially those related to digital media and personal communication - and focuses on the changing communicative construction of culture and society. Avoiding the dichotomy of these two traditions, Hepp (2013) proposes the metaphor of 'moulding forces' of media, indicating that one cannot presume a context-free 'effect' of a certain medium (p. 619). The various fields of culture and society, including politics and journalism, are communicatively constructed simultaneously across a variety of media (Hepp, 2013, p. 621). Consequently, Twitter as a site of networks between social and political actors holds discursive power as a part of the public sphere and its 'political publicity'.

The traditional elite networks have not disappeared but are sustained by various personal, face-to-face contacts and activities often in exclusive spaces for insiders. In addition, elites operate in the digital media environment and within the hybrid media system that combines traditional and new media (Chadwick, 2013). According to the study on Twitter networks between top-level politicians and journalists in Finland, virtual elite networks do exist - at least between these two elite groups. Equal access to elites, irrespective of social differences, is a prerequisite for a modern democracy and a key question in elite research, which contributes to the knowledge of the distribution of power between different social groups (e.g. Etzioni-Halevy, 1993; Mills, 1956; Mosca, 1939; Putnam, 1976).

\section{The virtual elite and the politics of presence}

In order to investigate the access to the virtual elite and composition of the Twitter elite, on one hand, and the relationship between the political and journalistic elites, on the other hand, the study employed the concepts of verticaland horizontal mobility used in elite research. Access to a virtual elite and its composition are measured by its vertical mobility. Vertical mobility measures the openness of the elite to being accessible to all members of society, irrespective of their social class, gender, ethnicity or other social differences. In the empirical analysis, the determinants of vertical mobility of the Twitter elite were gender, place of residence, party affiliation (politicians) and media affiliation (journalists). In other words, the more open the elite is for new members which represent a wide spectrum of social diversity, the more extensive is vertical mobility of that elite.

Horizontal mobility, on the other hand, refers to mutual coherence of different elite groups. In classical elite research, the concept of power elite (Mills, 1956) refers to a situation in which different elite groups are closely intertwined, thereby forming a coherent group. Such coherence can be measured by using the concept of horizontal mobility, according to which the more connections, interactions and mutual interests there are between different elite groups, the greater the coherence of the power elite. Conversely, the fewer connections there are between elites, the more fragmented the power elite is (Ruostetsaari, 2014, pp. 2831). 
If the virtual elite structure of the Twitter elite is characterised by weak vertical mobility and extensive horizontal mobility (dense networks between political and journalistic elites), the Twitter elite can be deemed exclusive. However, if horizontal mobility is weak, but vertical mobility is extensive, the Twitter elite can be viewed as fragmented. In general, an exclusive elite structure is inadequate, whereas a fragmented elite structure best meets the criteria of classical democracy (Ruostetsaari, 2006, 2014, p. 31). Dense and active virtual networks between political and media elites may be related to changes in the practices of political representation. Such changes are described in the theories according to which the model for representative democracy has changed from 'party democracy' to 'audience democracy' (Borg \& Paloheimo, 2009; Manin, 1997) or 'media democracy' (Meyer \& Hinchman, 2002). This new model of democratic practices reflects the consequences of structural and political changes as well as changes in the role of media in politics more explicitly, the mediatisation of politics. In audience democracy, political representatives and leaders are chosen on the grounds of their public image, while their credibility is largely built on, and maintained by, political publicity, and hence by media (Borg \& Paloheimo, 2009, p. 15).

The increased number of political scandals and expanding media coverage of the private and intimate lives of politicians are signs of an affective turn in politics. The intensifying competition in the media industry makes audience democracy profitable; thus, from the business perspective, political personalities and scandals become more important than taking up relevant political issues (Castells, 2007). The acceleration of political decision-making and the increasing number, and growing complexity, of political issues make it easier for voters to choose between political persons than between political programmes. Thus, the crisis of legitimacy coupled with the increasing complexity and unpredictability of political decision-making has led to a personification of politics that is typically defined in political science as a tendency of citizens to prefer voting for persons instead of parties.

Based on the empirical study, we assumed that politicians and political journalists are tied together in their Twitter networks by mutual interests. For politicians, this means being depicted in the most positive light in political publicity, and for journalists, it means having direct contact with key politicians to be the first to hear the topics of the day. Such interdependency between top-level politicians and journalists, who are the 'gatekeepers' of political publicity, can cause problems in terms of the democratic principles of journalism. Nevertheless, the existence of a Twitter elite consisting of a small group of people in top-level positions in politics and journalism would indicate a need to extend elite research to the hybrid media environment, which seems to constitute a new platform for political and journalistic (mediated) elites to get together and maintain their status.

The study focused not only on connections within and between political and journalistic elites in Finland but also between these elite groups and those whom they follow on Twitter. It asked whether these contacts constitute such tightly knit, cohesive networks that it would be justified to speak of the existence of an 'inner circle'. The existence of such a Twitter elite among top-level politicians and political journalists would indicate that the formation of elite networks may take place also in the digital environment. Furthermore, and especially, if these digital networks differ from traditional ones, it would strengthen the point that elite research of the digital age should include studies on the virtual communication, contacts and networks of elites. In other words, the study recognised a need for research that takes into consideration the mediatisation of elites, to which our term, 'mediated elites', refers. 
Even though Twitter's user base is small in Finland, with a population of about five and half million, it is considerably more significant than what one might think of on grounds of its size. Twitter is perhaps the most important social media service in the Finnish society that represents parliamentary democracy and a multi-party system. Twitter users have been calculated to be around 150,000 per month. Unlike, for example, in the United States, where Twitter is largely a "people's media", in Finland Twitter is an elite media that provides a platform for discussion with politicians, decision-makers and media representatives. This has been seen to be conducive to open issues and democratic decision-making, so Twitter's relevance to the political institution and news media has been studied relatively much in recent years. (Isotalus, Jussila \& Matikainen, 2018.) Despite the presence of the Twitter elite, there is little research about how how old elites are organized in relation to each other and what new elite groups have emerged in Twitter.

The object of the study is to contribute to the discussion on the ways digital media environment has affected the networking between and within the Finnish political elite and journalists specialized in politics and what this might mean for elite research. The following sections of the article present the main results of the empirical analysis of the Finnish networks within and between members of the political and journalistic elites of Finland. The study was aimed at answering the following questions: What kinds of networks have emerged within and between the Finnish top-level politicians and journalists on Twitter? What are the main characteristics of the mediatised elite assembled on and by Twitter, and who is included and excluded? Next, the results of the study are discussed in the context of theoretical discussions regarding the mediatisation of both politics and journalism, which we suspect has created new qualification requirements for top-level positions in politics and media. Finally, the study discusses the kinds of theoretical challenges elite research is facing due to the alleged changes in the networking (and even formation) of elites in the digital age.

\section{Social network analysis - method and data collection}

Thus far, there has been very little research on the virtual networks of elites established on social media (see, however, Ruoho \& Kuusipalo, 2018; Ruoho et al., 2014; Verweij, 2012). The method for finding elite networks among and between Finnish top-level politicians and journalists on Twitter was social network analysis. Conventionally, this method is used for investigating organisations or institutions and an actor's position within them, while the actor's structural position in the network is, to a lesser or greater degree, associated with his or her level of influence (Laumann \& Knoke, 1989, pp. 22-23). In this study, social network analysis was also employed to measure the coherence (horizontal mobility) of a Twitter elite consisting of two elite groups - top-level politicians and political journalists - as well as its openness or exclusivity (vertical mobility).

In order to identify elite networks and their mutual connections in virtual landscape an actor-based approach (Stieglitz \& Dang-Xuan, 2012) was used in a computer-assisted network analysis of a sample comprising individuals with Twitter accounts. Data mining and visualisation by force-directed algorithms made the networks visible. ${ }^{3}$ Visualising the networks allowed for displaying the basic characteristics of the whole network and its individual actors (nodes). The social network analysis produced visualisations of both elite networks and smaller clusters amongst them, illustrating the types of elite networks constructed in 'media- 
related practices' (Couldry, 2012, p. 35) or mediatising practices of elites provided by microblogging platforms.

To draw a sample representing the Finnish political elite, a list of politicians holding the highest positions in the Finnish political system was compiled. This list included cabinet ministers, Speakers of Parliament, chairs of parliamentary groups, chairs of parliamentary committees and leaders of political parties. Out of this group of 69 top-level politicians, only those who used Twitter (17 men and 17 women; total 34) were included in the sample of political elites. The sample of journalists ( 23 men and 16 women; total 39 ) included staff members representing political and domestic news from the largest national and regional newspapers and electronic media as well as journalists affiliated with the respective party newspapers. Subsequently, the accounts of those whom these two elite groups followed were included in the data. In sum, the data downloaded in December 2013 comprised the original samples of political elites and top-level political journalists (40 men and 33 women; total 73) and the top 50 Twitter accounts they were following.

The structure and hierarchies of networks were analysed by measuring the density and direction of the flow of information between individual Twitter accounts or nodes. Density refers to the overall connections between nodes, and it indicates the level of engagement in the network. Centrality reflects the number of connections each actor has in the network. Therefore, centrality measures can be used as indicators of popularity, power, influence and prestige (Scott \& Carrington, 2011). This can be evaluated by scrutinising one individual's linkages to other individuals. In a directed network, where we know the direction of the connection between nodes (from $A$ to $B$ or from $B$ to $A$ ), in-degree centrality shows how many links terminate at the node (incoming links), whereas out-degree centrality shows the number of links that originate in the node (Erlin \& Rahman, 2009).

In the following, the article takes up the key findings of the network analysis. The visualisations used as the basis for the analysis are typical examples of frozen snapshots of the Twitter networks at a specific moment.

\section{Twitter networks within and between political and journalistic elites}

\section{Top-level politicians and journalists on Twitter}

The visualisation of the Finnish political elite in Figure 1 includes the politicians in the original sample and the people they follow on Twitter. This makes it a structure-based network (Darmon, Omodei, \& Garland, 2014), where connections are formed by whom the members of the original sample follow. The colour of the node indicates party affiliation: red indicates the Social Democratic Party and the Left Alliance, blue indicates conservatives (the National Coalition Party) and green indicates the Green League (or Greens) and the Centre Party ${ }^{4}$. The size of the node corresponds to the number of incoming connections as an indicator of popularity. The more followers there are, the bigger the size of the node. 
Figure 1: Network visualization of the Twitter connections of the Finnish political elite by party affiliation.

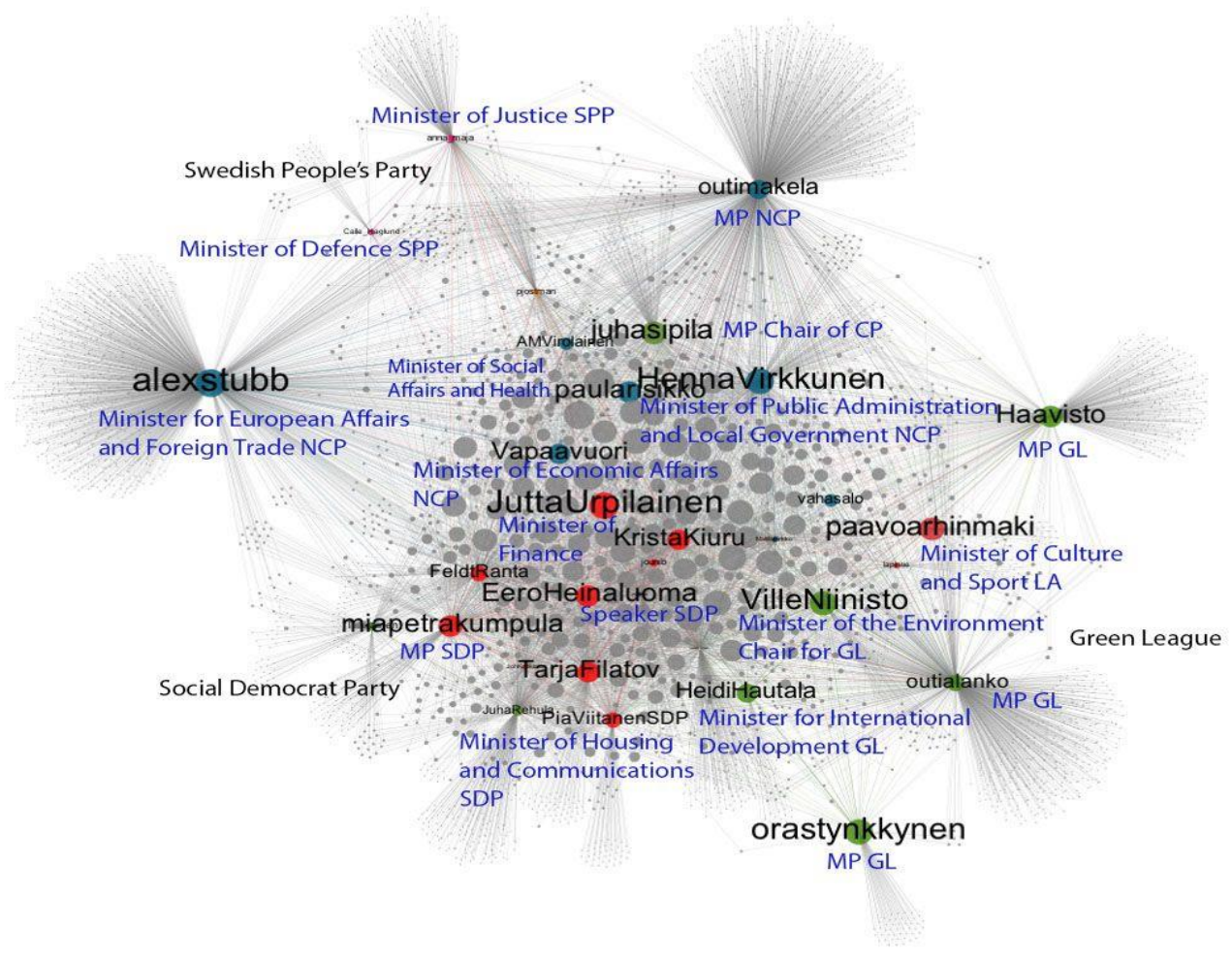

The visualisation depicts a rather dense political elite network consisting mostly of active users from the Social Democratic and National Coalition Parties, who are centrally located in the image. Representatives of the Centre Party and the Left Alliance are a minority, such as party leaders Juha Sipilä (Centre Party) and Paavo Arhinmäki (Left Alliance). At the time, the Centre Party was not in government ${ }^{5}$. The Swedish People's Party also stands out in the network with its own cluster in the upper-left corner of the image. Representatives of the Greens are all located on the right-hand side of the image, with those who are or have been ministers in the government located closer to the centre (Heidi Hautala and Ville Niinistö) than those who have not held positions in the government (Oras Tynkkynen and Outi Alanko). Former minister Pekka Haavisto is an exception.

Left- and right-wing parties seem to form their own sub-networks, as they align with different sides of the network. When force-directed algorithms are used, the nodes with many shared connections are drawn together. Therefore, the study can assume that the positioning of the right- and left-wing parties on their own sides of the constellation shows that they are more tightly connected to each other than politicians are in general. Nevertheless, Finnish politicians across party lines seem to follow each other, for example, in order to keeping up with what another party is discussing. The Finnish political sphere is diverse, as opposed to a polarised two-party system, such as in the United States.

Former Foreign Minister Alexander Stubb (National Coalition Party) and former Minister for International Development Pekka Haavisto (Greens) are located at the edges of the constellation because of their connections outside the core group. As the figure shows, they both have a significant number of individual 
connections that they follow outside the core of this network. This may imply that they use Twitter in a natural, 'twitteresque' way and not only in relation to their political activity in Finland; in other words, they also network outside the Finnish political sphere.

Compared to the politicians, journalists have a larger pool of Twitter accounts, which they follow. Further, the network of political journalists is larger than that of the political elite. Their different interests most likely explain this. Whereas journalists must seek out information from various sources, politicians use Twitter more for image management and campaigning. Previous research on social media and Finnish journalists has shown that most of the major Finnish media outlets have implemented social media guidelines, and they strongly encourage the use of social media (Noppari, Heinonen, \& Vainikka, 2014). While the data suggest that members of the Finnish political elite are more interested in other politicians' tweets, the Finnish political journalists seem to follow the tweets of the political elite. Journalists working for the oldest commercial television channel in Finland, MTV3, and those from the largest Finnish newspaper, Helsingin Sanomat (HS), are located close to their respective colleagues and have stronger ties among themselves. The core of the network is dense.

\section{Combined network of all politicians and journalists}

Figure 2 is a visualisation of virtual communities created at the intersection of journalists and politicians. In the sample, the most active Twitter user is a journalist working for HS, which focuses on national and metropolitan issues. Both political journalists and the political elite follow journalists Eeva Lehtimäki (MTV3) and Marko Junkkari (HS); in other words, these two are connecting nodes between the networks of politicians and journalists. Furthermore, there are some shared connections between the groups of political journalists and politicians. Both groups seem to follow the politics of the National Coalition Party and the Green League, which are popular in the metropolitan, urban areas of Finland. 
Figure 2: Visualisation of virtual communities created at the intersection of journalists and politicians.

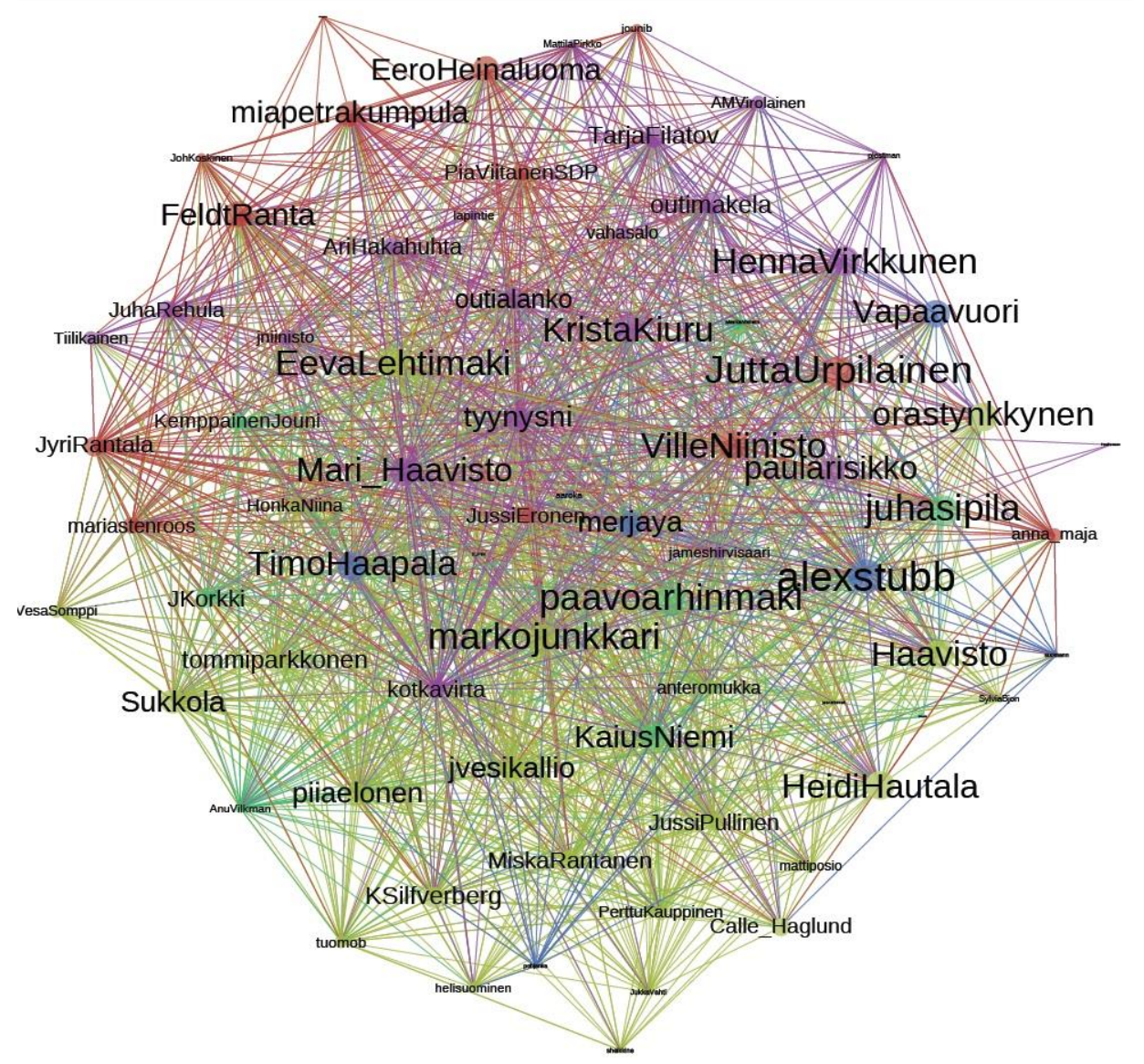

A parallel can be drawn from the findings of the network analysis to the Finnish elite groups, which Ilkka Ruostetsaari charts in his 2014 book, Vallan sisäpiirissä (The Inner Circles of Power). He determines that in comparison with the results of the parliamentary election, the supporters of the National Coalition Party and the Green League are overrepresented in the power elite, residing mostly in Southern Finland, while half of the members of the mass communication (media) elite vote for the National Coalition Party. Moreover, his study reveals that women constitute $43 \%$ of the political elite and $33 \%$ of the mass communication elite (Ruostetsaari, 2014, pp. 95, 120-122).

Among the members of the Twitter elite under the study (i.e. members of political and media elites who had a Twitter account in 2013), there was no significant difference between the representation of women and men. Based on our findings, the interactions between the political elite and top-level political journalists were relatively frequent, even though the politicians and journalists also had their own inclusive networks. It would appear that Twitter is a new forum for communication between elites. However, it also represents a new type of online public sphere, where even communication between elites is public.

Finally, there is some overlap of the networks of politicians and journalists (Fig. 3). The study combined the lists of the top 50 Twitter accounts followed by the journalists and the top 50 Twitter accounts followed by the politicians. The top 50 'tweeters to follow' list shows that 23 out of 50 accounts appear on both lists, making these Twitter users influential in the fields of both media and politics. On average, politicians and journalists follow 440 Twitter accounts. The top 10 most popular tweeters followed by politicians, journalists 
and the people they follow are four political party leaders, one prominent political journalist, four well-known political figures not included in the sample and an ex-editor of HS. They all belong to the traditional political elite or the media elite, while some of them operate both in the fields of media and politics. As Natalie Fenton and Veronica Barassi (2011) note, the mythic centre of media power also exists in social media networks. Accordingly, the core of the Finnish Twitter elite seems to represent such a mythic centre (cf. Couldry, 2012) on Twitter.

Figure 3: Overlap in the journalists and politicians 'top tweeters to follow' lists.

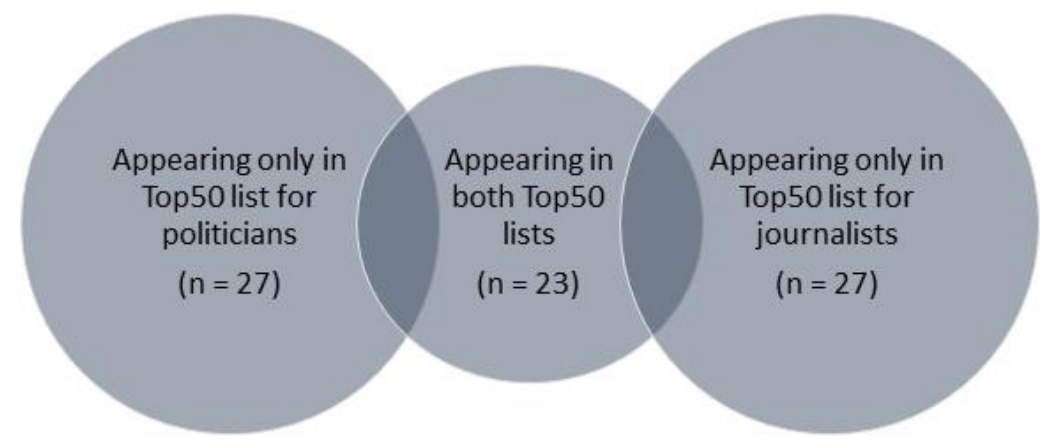

When comparing the lists of the 10 most followed accounts among politicians ${ }^{6}$ and journalists, respectively, the former includes three women, whereas the latter includes only one woman. This is surprising because, in terms of gender representation on Twitter, the Finnish political and journalist elites seem to be wellbalanced. However, among the top-level politicians and journalists and those whom they follow, it is mostly men that are at the centre of the network and, hence, at the top of the hierarchy.

\section{Mediated elites}

The Twitter network constructed from the visualisation of connections between members of the Finnish political elite and the people they follow suggests the emergence of a political Twitter elite or political 'twitterati' (cf. Verweij, 2012, p. 685). This group consists of in-service politicians who communicate via Twitter and who are widely followed. Not all members of this group are in institutional political positions, but some of them have previously held significant political positions. An institutional position is not an axiomatic indicator of popularity on Twitter, however. Twitter is a public space where top-level Finnish politicians and journalists operate. Using the Web also enables politicians and candidates to operate individually and relatively autonomously of the party by easily communicating on a personal level with members of the general public (Vergeer \& Hermans, 2013). From this, it is possible to conclude that the successful use of Twitter in terms of popularity (i.e. having a large number of followers) entails connections outside of one's professional status and communication unrelated to one's professional position.

The social network analysis and visualisations show that members of the Finnish political and journalistic elites follow each other intensively on Twitter and, therefore, form online networks and clusters both inside 
their own elite group as well as between each other. First, the results of the empirical analysis show that politicians are networked with each other along party lines. The visualisations of the networks also unveil the inner hierarchies of these elite networks - not all actors in the network have a large number of followers and are equally popular, and hence, equally influential. Popularity also indicates being influential in a network, since, unlike those who may follow many other actors but have few followers themselves, only the super nodes (i.e. those with the most followers) are, in fact, listened to by other members of the network. Furthermore, our results show that the most popular members of political and journalistic Twitter elites in Finland are men.

Second, the Twitter network between politicians and journalists reveals that members of these two elite groups follow the same 'super nodes' or key figures representing both politics and media. In other words, there is some overlap in the networks of political and journalistic elites. These findings refer to the existence of (an) online elite network(s) that can only be discerned online. Based on these findings, the study can conclude that the elites are increasingly mediatised. Consequently, political and media elites should be studied as products of mediatised processes of recruitment and formation of elites. Like politics, journalism is increasingly dependent on public recognition as a socially important institution (Kunelius \& Reunanen, 2016, p. 381).

Accordingly, the existence of online elite networks - as in this case, the political Twitter elite in Finland - is symptomatic and begs the following questions: Who among the top-level politicians and journalists in such a network are the most active and/or the most popular figures? What are they standing for? Moreover, what kind of (symbolic) power do they have? In the Finnish context, the most popular Twitter users in politics and political journalism can be conceived as a kind of 'elite among the elite'. Even the most popular political journalists on Twitter represent the most prestigious media houses in the metropolitan areas of Finland.

This means that the study does not support the notion that social media would induce a wave of democratisation (cf. Fenton \& Barassi, 2011). Nonetheless, the inner circles of the online networks of elites found in our study make the existing structures and hierarchies of power visible. Therefore, such research increases the transparency of the connections among the members of the power elite (Vainikka \& Huhtamäki, 2015, p. 172).

The fact that the characteristics of vertical mobility do not differ greatly between the Twitter elite and the Finnish power elite (outside of Twitter; see Ruostetsaari, 2014) does not confirm that extending public debate to social media enhances democracy. The analysis shows that in terms of gender, party affiliation, media affiliation and place of residence, the vertical mobility of the Twitter elite largely seems to correspond to that of the traditional Finnish power elite (Ruostetsaari, 2014).

In terms of gender, for example, the vertical mobility of the Twitter elite is less than what one would have anticipated in the case of the original sample. The list of top 10 individuals mostly followed by political journalists contains only one woman (Jutta Urpilainen, the first female leader of the Social Democratic Party and the first female Minister of Finance in Finland). Moreover, the list of people mostly followed by politicians contains only three women. This indicates that the female members of the Twitter elite are considered less 'noteworthy' than their male counterparts.

Overall, the composition of the Finnish Twitter elite indicates the ambivalence of online political publicity in terms of vertical mobility. On one hand, it enables free access to networks of power; on the other hand, the structure and characteristics of the networks between politicians and journalists expose a hierarchical and 
rather exclusive elite setting. While the communication between politicians and political journalists belonging to the Twitter elite is public and transparent in principle, the inner clusters of the Finnish virtual elite networks indicate that the Twitter elite seems to be concentrated in the hands of the privileged few. Furthermore, the observed overlap of the networks of politicians and journalists and the result that Finnish top-level politicians and journalists seem to form a quite coherent network (the Twitter elite) confirm our hypothesis concerning the horizontal mobilisation of these two elite groups.

\section{Conclusions}

The aim of the study was to contribute to the discussion on how the digital media environment has affected the networking between and within the political and journalistic elites and what this might mean for elite research. By studying the ways in which these elites establish networks on social media, the study contributes to the efforts to bring elite research into the digital era, which include research on mediated elites. Online presence and networks of top-level politicians and journalists reflect new mediated practices of both political communication and representation. Moreover, the study on elite networks on Twitter brings the critical question of the distribution and exercise of power into the virtual landscape.

Since the concepts of vertical and horizontal mobility refer to the tendencies for inclusion and exclusion, they bring us to the problems of power and democracy. The results of the empirical study on the Finnish political and journalistic elites reinforces the myth of the 'mediated centre', where actors from the spheres of media and politics come together and strengthen their interdependency and the existing power structure. Our results reveal that Twitter is maintaining this myth not only through the type of political communication that it encourages but also through the accounts/persons it helps win the game of visibility and popularity, as explained in this article. Belonging to the inner circle, or staying outside of it, seems to be as important an indicator of Twitter politics as the content of actual tweets. The structure of this inner circle of the Twitter elite may even reveal more about the social values held by the Finnish elite than the apparent content of their tweets. The myth of the mediated centre seems to persuade politicians and journalists from all levels of society to join a special kind of Twitter network dominated by the 'inner circle' of top-level political and media elites.

However, we are not arguing that Twitter alone frames or shapes such new mediated elites and their practices. One cannot presume a general or context-free 'effect' of any single medium (Hepp, 2013). Instead, Twitter is a 'moulding force' in a very material sense. For instance, it seems to encourage users to follow those accounts that are already widely followed. This supports Mark S. Granovetter's (1973) concept of 'weak ties': some well-known accounts may offer more useful news for their followers than others. The argument is not that all elite members know each other, though they might know a few other members very well. Rather, the point is that they are linked by an extensive series of weak ties. Accordingly, not all connections on Twitter are made with (well) known people; these may also include new online contacts ('weak links') that can be mobilised to provide information or assistance when needed. In the age of social media, weak-ties networking is even more common within the social structure than it was in the heyday of aristocracy (Savage et al., 2015, p. 133). 
Twitter symbolises for us a substantive transformation in the media environment that the elite research community should take seriously. Nick Couldry and Andreas Hepp (2017) argue that instead of emphasising the role of a certain medium, one should recognise 'a fundamental qualitative change in media environments' (pp. 38-39). According to their theory of 'deep mediatisation', today's digitalisation has fundamentally changed the whole media environment. Thus, mediatisation is a process whereby 'media have become increasingly relevant to articulating the kind of cultures and societies we live in, because of media's changing role in the conditions of human interdependence' (Couldry \& Hepp, 2017, p. 53).

Finally, we would like to argue that the digital media and hybrid media environments provide not only new forums for the elite but also a new kind of (practice of) political representation that is best captured by the concept of 'the politics of presence' (Rosanvallon, 2008). This concept refers to the requirement for political representatives to be continuously present for citizens or a particular audience - today, this includes being present on social media. The success of politicians, as well as democracy in general, is largely dependent on politicians' continuous presence and availability in the media. In this respect, presence has replaced representation (Rosanvallon, 2008, 2011, 2013, p. 279). Closeness and intimacy characterise this new relationship between politicians (representatives) and citizens (represented). When presence is expected and continuous, politics, in an institutional sense, is mediated in a new way as well - that is, attention is sought increasingly by and on social media.

\section{References}

Almgren, S. M., \& Olsson, T. (2016). Commenting, sharing and tweeting news: Measuring online news participation. Nordicom Review, 37(2), 67-81.

Borg, S., \& Paloheimo, H. (2009). Vaalit yleisödemokratiassa. Eduskuntavaalitutkimus 2007. Tampere, Finland: Tampere University Press.

Castells, M. (2007). Communication, power and counter-power in the network society. International Journal of Communication, 1, 238-266.

Chadwick, A. (2013). The hybrid media system: Politics and power. Oxford, UK: Oxford University Press.

Couldry, N. (2003). Media rituals: A critical approach. London. UK: Routledge.

Couldry, N. (2012). Media, society, world: Social theory and digital media practice. Cambridge, MA: Polity.

Couldry, N., \& Hepp, A. (2017). The mediated construction of reality. Cambridge, UK: Polity.

Darmon, D., Omodei, E., \& Garland, J. (2015). Followers Are Not Enough: A Multifaceted Approach to Community Detection in Online Social Networks. PLOS ONE, 10(8), e0134860. https://doi.org/10.1371/journal.pone.0134860

Erlin, N. Y., \& Rahman, A. R. (2009). Analyzing online asynchronous discussion using content and social network analysis. ISDA 2009, Intelligent Systems Design and Applications (pp. 872-877). International Conference on Intelligent Systems Design and Applications.

Esser, F., \& Strömbäck, J. (2014). Mediatization of politics. London. UK: Palgrave Macmillan.

Etzioni-Halevy, E. (1993). The elite connection: Problems and potential of Western democracy. Cambridge, UK: Polity Press. 
Fenton, N., \& Barassi, V. (2011). Alternative media and social networking sites: The politics of individuation and political participation. The Communication Review, 14(3), 179-196.

Freelon, D., \& Karpf, D. (2015). Of big birds and bayonets: Hybrid Twitter interactivity in the 2012 presidential debates. Information, Communication \& Society, 18(4), 390-406.

Graham, T., Jackson, D., \& Broersma, M. (2016). New platform, old habits? Candidates' use of Twitter during the 2010 British and Dutch general election campaigns. New Media \& Society, 18(5), 765-783.

Granovetter, M. (1973). The strength of weak ties. American Journal of Sociology, 78(6), 1360-1380.

Hepp, A. (2013). The communicative figurations of mediatized worlds: Mediatization research in times of the 'mediation of everything'. European Journal of Communication, 28(6), 615-629.

Hepp, A., Hjarvard, S., \& Lundby, K. (2015). Mediatization: Theorizing the interplay between media, culture, and society". Media, Culture \& Society, 372), 314-324.

Hepp, A., \& Krotz. F. (Eds.) (2014). Mediatized worlds: Culture and society in a media age. London, UK: Palgrave Macmillan.

Hjarvard, S. (2013). The mediatization of culture and society. London, UK: Routledge.

Isotalus, P., Jussila, J. \& Matikainen, J. (Eds.) (2018), Twitter viestintänä (Twitter as a communication). Tampere, Finland: Vastapaino.

Jensen, K. B. (2015). Review of Couldry: Media, society, world. International Journal of Communication, 9(3), 188-190.

Kammer, A. (2013). Mediatization of journalism. MedieKultur, 29(54), 141-158.

Kunelius, R., \& Reunanen, E. (2016). Changing power of journalism: The two phases of mediatization. Communication Theory, 26, 369-388.

Larsson, A. O., \& Moe, H. (2012). Studying political microblogging: Twitter users in the 2010 Swedish election campaign. New Media \& Society, 14(5), 729-747.

Lasorsa, D., Lewis, S., \& Holton, A. (2012). 'Normalizing Twitter: Journalism practice in an emerging communication space. Journalism Studies, 13(1), 19-36.

Laumann, E. O., \& Knoke, D. (1989). Policy network of the organizational state: Collective action in the national energy and health domains. In R. Perrucci \& H. R. Potter (Eds.), Networks of power. Organizational actors at the national, corporate and community levels (pp. 17-53). New York, NY: Aldine de Gruyter.

Lundby, K. (Ed.) (2009). Mediatization: Concept, changes, consequences. New York, NY: Peter Lang.

Manin, B. (1997). The principles of representative democracy. Cambridge, UK: Cambridge University Press.

Meyer, T., \& Hinchman, L. (2002). Media democracy. How the media colonize politics. Cambridge, UK: Polity Press.

Mills, C. W. (1956). The power elite. New York, NY: Oxford University Press.

Mosca, G. (1939). The ruling class. New York, NY: McGraw-Hill Book Company.

Noppari, E., Heinonen, A., \& Vainikka, E. (2014). Critical but co-operative - netizens evaluating journalists in social media. Observatorio $\left(O B S^{*}\right), 8(4), 1-16$.

Papacharissi, Z. (2016). Affective publics and structures of storytelling: Sentiment, events and mediality. Information, Communication \& Society, 19(3), 307-324. 
Putnam, R. D. (1976). The comparative study of political elites. Englewood Cliffs, NJ: Prentice Hall. Rosanvallon, P. (2011). Democratic legitimacy: Impartiality, reflexivity, proximity. Princeton, NJ: Princeton University Press.

Railo, E. \& Vainikka, E. (2017). A close-up on 'top tweeters' in Finland: Relevance of the the national context in political Twitter campaigning. Observatorio (OBS*), 11 (4), 90-104.

Rosanvallon, P. (2013). Demokraattinen oikeutus. Puolueettomuus, refleksiivisyys, läheisyys [La légitimité démocratique. Impartialité, réflexivite, proximité]. Tampere, Finland: Vastapaino. (Original work published 2008)

Ruoho, I., Kuusipalo, J., Vainikka, E., \& Huhtamäki, J. (2014). Twitter politics - democracy, representation and equality in the new online public spheres of politics. Retrieved from http://www.uta.fi/cmt/en/research/comet/projects/democracy political representation/index/ABS TRACT\%20TViittien\%20polititiikkaa\%20ENG\%2021.4.2015.pdf

Ruoho, I., \& Kuusipalo J. (2018). Läsnäolon valtaa: Politiikan ja median eliittiverkostot Twitterissä [Politics of presentation: Political and media elite networks on Twitter]. In P. Isotalus, J. Jussila, \& J. Matikainen (Eds.), Twitter viestintänä (pp. 51-65). Tampere, Finland: Vastapaino.

Ruostetsaari, I. (2006). Social upheaval and transformation of elite structures. The case of Finland. Political Studies, 54(1), 23-42.

Ruostetsaari, I. (2014). Vallan sisäpiirissä. Tampere, Finland: Vastapaino.

Savage, M., \& Gunningham, N., Devine, F., Friedman, S., Laurison, D., Mackenzie, L. . . . Wakeling, P. (2015). Social class in the $21^{\text {st }}$ century. London, UK: Penguin Random House.

Scott, J., \& Carrington, P. (2011). Introduction. In J. Scott \& P. Carrington (Eds.), The SAGE handbook of social network analysis (pp. 1-8). London, UK: Sage.

Stieglitz, S., \& Linh Dang-Xuan, L. (2012). Social media and political communication: A social media analytics framework. Social Network Analysis and Mining, 3(4), 1277-1291.

Twittercensus. (2013). Finnish Twitter census 2013. Retrieved from http://twittercensus.se/twittercensus$\underline{2013 /}$

Vainikka, E., \& Huhtamäki, J. (2015). Tviittien politiikkaa - poliittisen viestinnän sisäpiirit Twitterissä. Media \& viestintä, 38(3), 165-183.

van Dijck, J. (2013). Tracing Twitter: The rise of a microblogging platform. International Journal of Media and Cultural Politics, 73$), 333-347$.

Vergeer, M., \& Hermans, L. (2013). Campaigning on Twitter: Microblogging and online social networking as campaign tools in the 2010 general elections in the Netherlands. Journal of Computer-Mediated Communication, 18(4), 399-419.

Verweij, P. (2012). Twitter links between politicians and journalists. Journalism Practice, 6(5-6), 680-691.

Witschge, T. (2014). Passive accomplice or active disruptor: The role of audiences in the mediatization of politics. Journalism Practice, 8(3), 342-356.

\footnotetext{
${ }^{1}$ Empirical analyses concerning political communication on Twitter have shown that this social media platform is increasingly used for political debates, agenda setting and cultivating the public images of political personalities; however, most of these studies have examined the role of Twitter in election campaigns or how the social media site facilitates sharing online news (e.g. Almgren \& Olsson, 2016; Freelon \& Karpf, 2015; Graham, Jackson, \& Broersma, 2016; Larsson \& Moe, 2012; Parmelee, 2013; Vergeer \& Hermans, 2013).
} 
2 The publication Twitter politics - democracy, representation and equality in the new online public spheres of politics (Ruoho, Kuusipalo, Vainikka, \& Huhtamäki 2014) is a summary of the main results of the cross-disciplinary research project "Democracy, Political Representation and Equality in New Online Publicities for Political Communication". This project funded by The Foundation of Helsingin Sanomat was led by Iiris Ruoho and conducted in the Tampere Research Centre for Journalism, Media and Communication (COMET) in 2013-2014. The project included two sub projects: the one on Twitter networks between top-level politicians and political journalists (Ruoho \& Kuusipalo 2018; Vainikka \& Huhtamäki 2015) and the other focusing on the use of Twitter in the electoral campaigns of the Finnish candidates of the European Parlamentary Elections in 2014 (Railo \& Vainikka 2017). What this article adds to the previous publications mentioned above, is an analysis and discussion of the new ways in which social media rearticulates the practices and concepts of political communication and representation in the context of elite research.

${ }^{3}$ In this study, the Twitter data were retrieved through the Twitter API using a tailored batch processing script in Python. The network was visualised using the open source network visualisation software Gephi. We used force-directed graphdrawing algorithms for the visualisation. In such algorithms, nodes repel each other and edges act as springs drawing the nodes towards each other. When these forces are left to operate over a period, the nodes that have more connections appear close to each other in the resulting layout.

${ }^{4}$ When the data were collected (2013), the four largest political parties in Finland were, in order, the National Coalition Party (Kokoomus), the Social Democratic Party of Finland, the Finns (Perussuomalaiset) and the Centre Party (Suomen keskusta). The smaller political parties included the Left Alliance of Finland (Vasemmistoliitto), the Greens of Finland (Vihreä liitto), the Swedish People's Party (Suomen ruotsalainen kansanpuolue) and the Christian Democrats (Suomen Kristillisdemokraatit).

${ }^{5}$ When the data were collected (2013), the Finnish government was led by Jyrki Katainen (National Coalition). Apart from the National Coalition Party ( 6 cabinet ministers: 4 men and 2 women) and Social Democratic Party (6 cabinet ministers: 2 men and 4 women), the Left Alliance (2 cabinet ministers: 1 man and 1 woman), Greens (2 men) and Swedish People's Party (1 man and 1 woman) each had two cabinet ministers, and the Christian Democrats had one female cabinet minister.

${ }^{6}$ In order of popularity: (1) @MikaelJungner, outside the sample; (2) @alexstubb, politician; (3) @JuttaUrpilainen, politician; (4) @jmpentikainen, outside the sample; (5) @AnniSinnemaki, outside the sample; (6) @anttikaikkonen, outside the sample; (7) @markojunkkari, journalist; (8) @paavoarhinmaki, politician; (9) @juhasipila, politician; (10) @TarjaHalonen, outside the sample. 